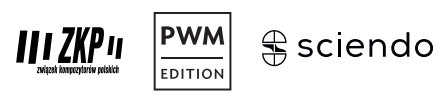

\title{
"Let Us Create a Modern Lithuania!" Confrontations of National Identity with Modernity in the Lithuanian Music Modernisation Discourse of the 1930 s
}

\author{
RŪTA STANEVIČI ŪTE \\ Lithuanian Academy of Music and Theatre, Vilnius, Lithuania \\ Litewska Akademia Muzyki i Teatru \\ $凶$ ruta.staneviciute@gmail.com \\ DOI: $10.2478 /$ prm-2021-0008
}

The project of modernisation was the central idea that emerged in the course of twentieth-century Lithuanian music. In the interwar years, a number of influential yet very different versions of Lithuanian modernism were formulated by composers Juozas Gruodis (1884-1948), Vladas Jakubėnas (1904-1976), Vytautas Bacevičius (1905-1970), and Jeronimas Kačinskas (1907-2005). Their vision of modern national music was shaped to a great extent by the urgent need to construct a modern musical identity in the new political and cultural context. During the interwar period, the paradigm of national musical culture took shape under the influence of political and cultural aspirations fuelled by the newly-created modern Republic of Lithuania. At the root of Lithuanian projections of musical modernism lies a central concern with questions of national identity, affected by crucial historical changes and political processes. The shift in the re-assessment of inherited cultural traditions might be illustrated with the change of foreign cultural identifications as represented by newly emerging centres of attraction for composition studies. From the mid-1920s, young Lithuanian composers were attracted to Paris,

„Stwórzmy nowoczesna Litwę!” Konfrontacja tożsamości narodowej i nowoczesności w dyskursie o modernizacji muzyki litewskiej w latach $30 . \mathrm{XX}$ wieku

(C) 2021 by Rūta Stanevičiūtè. - This is an open access article licensed under the Creative Commons Attribution-ShareAlike International (CC-BY-SA 4.O) https://creativecommons.org/licenses/by-sa/. 
Berlin, and Prague which overshadowed the places previously considered as hubs for Lithuanian musicians: Leipzig, Warsaw, Riga, Moscow, and Saint Petersburg. In this way, the neighbouring countries - Russia, Poland and the more conservative part of Germany - were replaced by the musical metropolises of Western and Central Europe. Among the most influential figures of the younger generation was composer and conductor Jeronimas Kačinskas, an alumnus of the Prague Conservatory, where he had studied quarter-tone composition with Alois Hába; composer and pianist Vytautas Bacevičius, who studied in Paris and affiliated himself with the so-called School of Paris; and composer Vladas Jakubėnas, who studied composition with Franz Schreker at the Hochschule für Musik in Berlin. They were joined by some other young musicians with a similar musical background.

Musicians who completed their education in the West in the 1920 and 1930 s and later returned to the homeland found it difficult to integrate in Lithuania. Despite the rapid progress of the state, the network of musical institutions in Kaunas, the temporary capital of Lithuania, was poor at that time. Concerts of symphonic or chamber music, mainly held due to the efforts of a private Philharmonic Society, slumped after the global economic crisis, and the publication of music periodicals ceased as early as in the late 1920s. The composers' dissatisfaction was also fuelled by the activity of the State Theatre and the radio. It was in the late 1920s that the efforts of musicians of different generations and artistic platforms began to concern the pressing problems facing musical culture. Consequently, undertaking decisive reforms in the musical scene became an area and aim of especially intense activity. Musical movements, private societies, and other groups began to form spontaneously. In that environment, due to the efforts of Kačinskas, Bacevičius, and other young musicians, a shortlived Society of Progressive Musicians was founded in 1932, the journal Muzikos barai [Fields of Music] was launched in 1931, the journal Muzika ir teatras [Music and Theatre] followed in 1933, and the Lithuanian section of the ISCM was founded in 1936. All of these functioned as typical institutions of the modernist music movement. Their activities and contributions to the modernisation of Lithuanian musical culture were most 
strongly affected by Kačinskas' contacts with the Hába school and the modern music scene in Prague.

However, when it came to defining cultural identity and possibilities of its representation in Lithuanian music, the opinions of these composers diverged. Consequently, public discussions on the subject of national and modern elements in music appeared in the music press of the 1930 s and became emblematic of subsequent Lithuanian music history. Among the most active participants of those debates were young composers: $\mathrm{Vy}$ tautas Bacevičius, Jeronimas Kačinskas, and Vladas Jakubėnas. All the opposed parties criticised declarative representations of nationality, typically associated with the use of folklore. The main bone of contention was the use of modern musical language to express national character and the very definition of national identity itself. In a similar way as in a number of other countries, where discussions on new music also took place at that time, in the Lithuanian debates problems related to the nature of musical representation interacted with individual artistic choices and views concerning the potential of preferred stylistic trends. However, these diverse constructions of musical identity were strongly influenced by the composers' experience of studies abroad and their transcultural affiliations. In that context, I shall present the main arguments of the debates' participants as representative projects for national music modernisation which implanted influential narratives of identity and renewal in Lithuanian music.

\section{Lithuanian Projects for Radical Modernism}

Jeronimas Kačinskas merits a very important place in the modernisation narratives of Lithuanian music, where he is regarded as a radical modernist. Such reception of his music formed in the interwar years. In Lithuanian music criticism of the time, both Kačinskas and Bacevičius were labelled "ultramodernists," while their music was classified as "expressionistic atonalism." The question of whether these two composers can be numbered among the avant-garde remains open until this day and is still being 
discussed by Lithuanian musicologists. ${ }^{1}$ The early reception of Kačinskas' music was certainly influenced by his work as an active advocate of the Hába school and promoter of other modernist trends in Lithuania. In his output and cultural activities, Jeronimas Kačinskas strongly advocated radical modernisation of national tradition. After his return from Prague to Lithuania in 1931, Kačinskas opened a quarter-tone theory class at the Klaipeda Music School and publicised the phenomenon of microtonal music in the local press by printing articles by Alois Hába, Karl Ančerl, Karel Reiner, Mirko Očadlík, and other members of the Hába school in the journal Muzikos barai [Domains of Music], which he had co-founded and co-edited with fellow musicians from 1931 onwards. The spread of the quartertone music in Lithuania also gathered momentum due to the activity of the Society of Progressive Musicians, a group of congenial artists who gathered around Kačinskas in 1932 and organised the first Lithuanian tour of the then famous Czech Nonet in the same year. It was during that tour that the first version of Kačinskas' Nonet (1931-1932/1936) received its Lithuanian premiere, performed by its dedicatee, and was later included in the program of the 1938 IsCM Festival in London.

Kačinskas presented the progress of Czech musical culture as an example to be followed when modernising Lithuanian musical culture:

\begin{abstract}
It is necessary for us, Lithuanian musicians, to become better acquainted with the achievements of the Czechs and other nations in the art of music and to adapt them for our own culture. Otherwise, in the future, we shall unavoidably face the threat of lagging behind the world and of stagnation that leads nations to destruction. ${ }^{2}$ (Transl. by the author)
\end{abstract}

In his writings from that period, Kačinskas, like Hába's numerous other more famous pupils, focused most frequently on developing the music philosophy of their composition teacher. In the Lithuanian context, Kačinskas proposed an original way of modernising national music. He rejected

1 The more thourough discussion of Vytautas Bacevičius relationships with the international music avant-garde was occasioned by his centennial celebrations in 2005. Cf. Vytautas Bacevičius in Context, eds. Rūta Stanevičiūtè, Veronika Janatjeva (Vilnius: Lithuanian Composers' Union, 2009).

2 Jeronimas Kačinskas, "Naujoji čekų muzika" [New Czech Music], Muzikos barai 2 (1931), 4. 
superficial adaptations and imitations of Western influences. For Kačinskas, the basis of national uniqueness lay in creative individuality, which never repeats the previous stages of human creation and is based on "free creative foundations":

We live in an age when science and art manifest themselves in an especially intense development and search for new ways. The mind is penetrating into still unexplored areas in order to learn everything and to adapt that knowledge to life. The love of diversity and a desire to get rid of all clichés are strongly felt. Art has always been sensitive to the character of the age; thus currently it also reflects some qualities of our life. However, it would be inaccurate to assume that art's ideological expression always strongly depends on the character of the age. Frequently it reaches much further. [...] Traditionalism in music only paralyses its progress, since limitations have a bad impact on the creator's imagination and prevent him from taking advantage of all the roads of artistic beauty. Free development of creation within the boundaries of the artist's control over feelings and mind is therefore the closest we can come to progress. ${ }^{3}$ (Transl. by the author)

As evident from Kačinskas' reflections on creativity, he doubtlessly followed Hába's concept of the music of freedom, which represented the doctrine of aesthetic freedom typical of the Central European avant-garde. At the technical level, it was to express itself in athematicism and microtonality - unrestricted freedom of choice in formal development and musical material. Promoting the ideology of the music avant-garde, the Lithuanian composer in a way accepted the critical re-interpretation of unique national tradition in the context of contemporary microtonality:

Quarter-tone and sixth-tone systems of composition implemented in Prague are nothing more than a development of primeval Oriental music combined with European music culture. [...] According to some famous Prague musicians, the Lithuanian people are closer to the Orient than to Western European spirit; they have observed Lithuanian musical rhythms and the character of our melodies. If we look at our music in the past, we will find there a number of intervals smaller than semitones. It is known that in the ancient times Lithuanians did not know Greek and German major and minor tonalities. ${ }^{4}$ (Transl. by the author)

3 Ibidem, 1.

4 Ibidem, 4 . 
However, unlike Hába, Kačinskas was critical (from the very beginning of his musical career) of the opinion then widespread in Lithuania that modern music had to be based on the "structure and spirit of the old folk songs" ${ }^{5}$. The desire to create a model for national music through a mechanical generalisation of expressive means taken from traditional music (its melodic, rhythmic, and harmonic features) was considered by the composer to be a constraint or even a hindrance for new music as well as an element that limited its progress. It is interesting to note that after the 16th ISCM Festival in London (1938), Kačinskas stated that "creative power now lies in Europe's eastern and south-eastern states: Czechoslovakia, Yugoslavia, Hungary, Poland, and Lithuania" ${ }^{6}$.

Positioning Kačinskas as a progressive composer was strongly supported by Vytautas Bacevičius, who in turn proposed his own original concept of representing both modernity and nationality in music. Bacevičius was an artist of a dual cultural identity; born into a mixed Lithuanian-Polish family and educated in Poland, he arrived in Kaunas in 1926, determined to contribute to the culture of his second motherland, that of Lithuania. However, representing Lithuanian identity in his compositions only became relevant to him after he had left the country to study in Paris (1927-1930), under the influence of French modernism, Igor Stravinsky, and the Paris School. He identified himself with the music scene in Paris as the world's art capital and simultaneously selectively evaluated the established trends in modern music (neo-Classicism, neo-folklorism, "lifestyle modernism," "machinism," surrealism, etc.). In Paris, the composer's modernist style evolved. The line of his early cosmic music was continued with Poeme No. 4 for piano (1929), which enriched the impulses of late Scriabin with post-impressionistic harmonies. The opera Vaidilute [The Priestess], composed in the same year, and Concerto for Piano and Orchestra (on Lithuanian themes) map out the transition between his

5 Jeronimas Kačinskas, "Tautiškos lietuvių muzikos kūrybos klausimai“ " [On the Issues of Lithuanian National Music], Muzikos barai 2 (1933), 22.

6 St. Mac., "Kompozitorius Jeronimas Kačinskas apie muzikos festivali Londone” [Composer Jeronimas Kačinskas on the Music Festival in London], Vakarai (9th July 1938). 
early compositions and several subsequent Paris-inspired pieces, such as the cabaret-style ballet In the Whirl of Dance [Šokių sūkuryje] (1932), the nostalgic Valse-Ballet (1932), and the machinist Poème électrique (1932), which marked an unexpected turn towards Lithuanian themes and the neo-folkloristic style. Although Bacevičius did not maintain contacts with the school of Paris, which brought émigré musicians together, he was to some extent associated with it.

After his studies in Paris, the composer actively integrated into Lithuanian musical culture. Before World War II his successful international career as a pianist and composer was coupled with his work as a music critic. Bacevičius and Kačinskas were the strongest opponents to the mainstream of national modernism, and were especially critical of the narrow concept of musical nationalism. Bacevičius promoted creative individualism and a specific idea of cosmic music ${ }^{7}$, while he associated progress in national music with the universal culture modernisation program. He sought to capture those elements of life that characterised the spirit of the twentieth century. ${ }^{8}$ The composer persistently propagated the image of "triumphant modernism" in the Lithuanian cultural environment. What Bacevičius valued most in music were universality and individuality of its expression, rather than the composer's national aspirations. Atonality was for him the synonym of modern music as it conquered tradition and expressed the new age; this attitude is reflected in a quotation from his letter to his sister Grażyna Bacewicz from 1958: "What nationality am I? That's very simple! My nationality is music. And what race am I? Atonal. That's it" 9 .

7 Vytautas Bacevičius' cosmic music represents one of the many varieties of utopian thinking among twentieth-century composers. He believed that the visionary powers of music lay in its abstract expression. Bacevičius saw not only abstract music (the only essentially modern music) but also abstract visual art as real cosmic music. For more on this subject, see Małgorzata Janicka-Słysz, Vytautas Bacevičius i jego idee muzyki kosmicznej [Vytautas Bacevičius and his Ideas of Cosmic Music] (Kraków: Akademia Muzyczna w Krakowie, 2001).

8 Vytautas Bacevičius as cited in: “Naujas V. Bacevičiaus kūrinys" [V. Bacevičius’ New Work], Muzikos barai 3 (1932), 38.

9 Letter to Grażyna Bacewicz, New York, 9 September 1958. Quoted after Vytautas Bacevičius. II tomas. Ǐsakyta žodžiais [Vytautas Bacevičius. Volume 2. Put into Words], ed. and transl. Edmundas Gedgaudas (Vilnius: Petro Ofsetas, 2005), 45. 
Bacevičius' concept of cosmic music was probably the most radical and consistent programme that appeared within Lithuanian twentieth-century music. It paradoxically combined two seemingly incompatible goals, those of promoting the contemporary as a value orientation and of forming a utopia for the music of the future. Can art change the world by creating a counter-reality? He not only (and not simply) strove to reform the composition practice, but also proposed a modern understanding of music intended to ensure progress in art and society. ${ }^{10} \mathrm{He}$ was also concerned about Lithuania's progress as a state and the revival of Lithuanian culture:

[...] it is already time to be concerned about and take an interest in new achievements in the field of art; it is already time to create artistic values which agree with the spirit of the twentieth century [...]. Let us create a modern Lithuania! ${ }^{11}$ (Transl. by the author)

\section{Between National Identity and Lithuanian Character}

Vladas Jakubènas' output diverged from those of Bacevičius and Kačinskas, whose works abounded in musical novelties. As the main opponent of his young colleagues, after the completion of his studies he used critical analysis to oppose the modernist experience in music and turned quite radically towards a more moderate national style of music. Vladas Jakubènas, who studied in Franz Schreker's composition class at Berlin's Staatliche Akademische Hochschule für Musik (1928-1932), was already distancing himself from his teacher's artistic ideology during his studies under the strong influence of Paul Hindemith's neo-Classical music (Prelude and Triple Fugue for String Orchestra, 1928-1929; Melody-Legend for violin and piano,

10 Bacevičius even ventured to prepare a project for the improvement of state structure, which he was hoping to present to the President of Lithuanian Republic, see Rūta Stanevičiūtè, Modernumo lygtys. Tarptautine šiuolaikinés muzikos draugija ir muzikinio modernizmo sklaida Lietuvoje [Figures of Modernity. International Society for Contemporary Music and the Modern Music Movement in Lithuania] (Vilnius: VDA, 2015), 244.

11 Vytautas Bacevičius, "Apie tautišką muziką" [On National Music], Naujoji Romuva 9/371 (1938), 216-217. 
1930-1931; String Quartet, Op. 4 - version 1, 1929-1930, and version 2, 19311932; Symphony No. 1, 1931-1932). Jakubėnas took part in the activity of the Berlin Chapter of the ISCM German Section. His early works composed in Berlin were therefore performed in the concerts held by that organisation and in Schreker's class. In later years, he continued to be rather selective in his evaluation of the topical phenomena of the new music scene in Berlin. He programmatically belittled or even ignored some of them (e.g. the Neue Sachlichkeit, Arnold Schönberg's school, or technology-inspired music).

In his interwar publications in Lithuanian press, Jakubènas - already recognised as the best music critic of the time - rejected the currents of radical modernism as pointless experiments and as music for a narrow circle of experts, one that "started digging a deep ditch between specialists in new music and the general public," scared away performers, reduced the demand for new compositions in concert programs, and unsettled the individual styles of young composers. ${ }^{12}$ Jakubènas was critical of modern music due to the stylistic tools it uses in the first place and less so because of differences in worldviews: "The new generation and the new psychology appear to be much simpler, non-metaphysical, brutal and barbaric" 13 . Directly after his studies in Berlin, he wrote a number of articles concerning the clarity of musical ideas and the lucidity of tools that composers employ. For instance, he criticised Bacevičius for his taste for a large number of instruments playing all at once. In Jakubėnas' words, Bacevičius apparently wanted to attain the maximum sound mass at any given point in time, "a lot of noise" 14.

Jakubenas was just as baffled by the absence of social function in the arts, an aspect that he believed was completely disregarded in new music. Paradoxically, however, he saw the future of music in the revival of romantic worldviews and the cultural function. This was not because he wanted to follow the classics of Lithuanian Romanticism, but rather because he

12 Vladas Jakubėnas, "Moderniosios muzikos krizė" [The Crisis of Modern Music], Vairas 2 (1933), 213-218.

13 Ibidem, 215 .

14 Vladas Jakubėnas, "Iv Filharmonijos koncertas" [The Fourth Philharmonic Concert], Lietuvos aidas (10th January 1934), 8. 
declared his own programme to be a return to selected traditional values. As a composer he was immersed in an arduous search for a formula of the national style and was simultaneously making attempts to distinguish nationalism from Lithuanianness in music as two different concepts. For Jakubenas, Lithuanian character was a product of the rural environment, distinct from the modern experience of urban life. Jakubenas' stance is closely related to the cultural environment in Lithuania in the 1930s, when the society was growing increasingly critical towards modern, particularly avant-garde art; the search for a monumental national style and functional art was underway in many areas of artistic creativity. The proposed model for national music that Jakubènas wished to convey was best represented by his ballet Vaivos juosta [Vaiva's Belt ${ }^{15}, 1939-1943{ }^{16}$. While writing this work, the composer looked into Lithuanian mythology in search for deeper structural ties between musical means and national identity. A merely decorative use of folklore could not satisfy Jakubènas, who maintained that such a creative method did not ensure the distinctiveness of national music. In retrospect, the established argument that Jakubenas' return to neo-tonality and tradition during that period should be seen as a surprise move away from modernism seems rather less convincing. ${ }^{17}$ Taking into account his social and cultural aspirations, he seems to have been right as far in the choice of that particular genre and stylistic model. His ballet

15 In the Lithuanian mythology Vaiva, the goddess of rain, weaved a beautiful belt which appears occasionally in the sky as the rainbow. Jakubenas set a libretto by Vincas Krèvè-Mickevičius, one of the representatives of Lithuanian classical literature, who rewrote his own myth-based story Perkūnas, Vaiva and Straublys (1920) for the ballet.

16 The fate of Vladas Jakubenas only stage piece, the ballet Vaivos juosta [Vaiva's Belt], was particularly dramatic. The ballet that Jakubènas began writing in 1939 was scheduled for a premiere in 1942 according to the contract with the Kaunas Theatre. During the years of Nazi occupation, the score disappeared in the Kaunas Jewish Ghetto along with Leiba Hofmekler (1900-1941?), a conductor and experienced interpreter of ballet music who was reading it at that time. Jakubenas restored the music from memory in 1943. Nevertheless, it was not before December 2014 that Vaiva's Belt was staged in Vilnius for the first time ever.

17 Cf. Rita Nomicaite, "Vladas Jakubėnas (1904-1976)," in Lietuvos muzikos istorija, Kn. 2: Nepriklausomybes metai, 1918-1940, ed. Algirdas Ambrazas. Vilnius: Lietuvos muzikos ir teatro akademija, 2009, 587-599. 
Vaiva's Belt symptomatically finds its place within the current of mid-twentieth-century neo-traditionalism, which was vastly influenced by political and cultural changes and stimulated the creation of monumental and functional art (especially in totalitarian states), a great many examples of which would emerge over the next several decades.

Public debates between the above-mentioned antagonists reached their climax following Jakubènas's publication of articles on Lithuanian music (1938), marking the twentieth anniversary of the Lithuanian Republic. ${ }^{18}$ In his texts, Jakubenas dismissed Kačinskas and Bacevičius as genuine Lithuanian artists, and labelled them as representatives of international modernism. Both Kačinskas and Bacevičius reacted violently in their critical responses. ${ }^{19}$ Below I will briefly summarize the composers' arguments:

- Vladas Jakubenas - Lithuanian music is a representation of Lithuania's nature, its historical past, the character of its people, and the moods of the Lithuanian folklore. Lithuanian character is a product of rural environment, deeply rooted in lyricism and very distinct from the modern experience of city life. Lithuanianness in music has two main aspects: the national one derived from folk songs and the cultural one as represented in composed professional music.

- Vytautas Bacevičius - Lithuanian music should represent the contemporary achievements of the modern Lithuanian nation. The Lithuanianness of musical works lies in the artist's identification with the native cultural environment.

- Jeronimas Kačinskas - representations of nationality in new Lithuanian music require a much broader definition of national character. Creative individuality is the foundation of national culture. The ability to create is characteristic of individuals only.

18 Vladas Jakubėnas, "Kaip augo mūsų muzika” [How Our Music Grew], Lietuvos aidas (15th February 1938), 5; idem, “Tautinès muzikos klausimais. Atsakymas V. Bacevičiui” [On the Issues of National Music. Answer to V. Bacevičius], Naujoji Romuva 14/376 (1938), 346-348.

19 Bacevičius, “Apie tautišką muziką," 216-217; idem, "Dar apie tautišką muziką” [Again About National Music], Naujoji Romuva 15-16/377-378 (1938), 370-371; Jeronimas Kačinskas, "Muzika Lietuvoje" [Music in Lithuania], Naujoji Romuva 47/40o (1938), 3-6. 


\section{Interwar Debates and Their Postwar Reception}

The debates between Jeronimas Kačinskas, Vytautas Bacevičius, and Vladas Jakubenas on the subjects of modern art and the national identity served as important stimuli for the modernisation of music in Lithuania before World War II. The inclusion of relevant issues of Lithuanian music in both the national and international modernisation context indicated a significant shift in Lithuanian cultural self-awareness and composers' self-image. The polemical observations, insights and statements made in the interwar period were effectively elaborated in later reception and served as the basis for a reinterpretation and revision of the Lithuanian music modernisation discourse. These debates on modernity and nationality provided a fresh impetus for emblematic discussions on (non-)representation of national character in modern music, stimulated in the late 1970 os by composer Osvaldas Balakauskas, a representative of the Lithuanian second avant-garde. ${ }^{20}$ Balakauskas strongly supported a position in some ways similar to that by Jeronimas Kačinskas, and was sharply criticized by musicologists Algirdas Ambrazas and Vytautas Landsbergis among others. ${ }^{21}$

The political events of the mid-twentieth century (the Soviet occupation, World War II, and the beginning of the Cold War) brought an end to the Lithuanian modern music movement and "destroyed all the work that had been done and the hopes for broad international collaboration with the progress of music worldwide" 22 . After World War II, the composers Jeronimas Kačinskas, Vytautas Bacevičius, and Vladas Jakubenas emigrated to the USA. In the years of the Cold War, political tensions and

20 Osvaldas Balakauskas, "Praradimai ir atradimai" [Loss and Discovery], Literatūra ir menas (4th February 1978).

21 Algirdas Ambrazas, "Ko nederètų prarasti" [What Should Not Be Lost], Literatūra ir menas (18th February 1978); Vytautas Landsbergis, "Pūtè vejjas akmenį" [The Wind Blew The Stone], Literatūra ir menas (4th February 1978).

22 A letter from Jeronimas Kačinskas to Juozas Žilevičius, Augsburg 1947 (?). Quoted after Jeronimas Kačinskas. Gyvenimas ir muzikinè veikla. Straipsniai, laiškai, atsiminimai, [Jeronimas Kacinskas. Life and Musical Activities. Articles, Letters Memoirs], ed. Danutė Petrauskaitè. Vilnius: Baltos lankos, 1997, 241. 
ideological constraints heavily influenced the dissemination of the interwar period musical modernism and its reception in Soviet Lithuania. However, eventually the ambitions of the official cultural policy-makers to control the interpretations of musical heritage eased off. The return of interwar modern music to the cultural space of Soviet Lithuania was stimulated by the somewhat later interest of the younger generation of composers and performers in their works; it correlated with the second period of national music modernisation. However, till the very end of the Soviet period, the works of Bacevičius, Kačinskas, Jakubènas, and other pre-war modernists did not become an integral part of Lithuanian musical life. ${ }^{23}$ Therefore, in the Soviet years, the early Lithuanian modernist movement functioned more as an influential narrative or a legend concerning part of a lost culture than an actual set of musical works and a living musical experience. However, the interwar efforts for a re-figuration of national identity in music left a deep imprint on Lithuanian discourse about music, as a never completed modernisation project. ${ }^{24}$

\section{BIBLIOGRAPHY/BIBLIOGRAFIA}

Algirdas Ambrazas, "Ko nederètų prarasti” [What Should Not Be Lost]. Literatūra ir menas (18th February 1978).

Vytautas Bacevičius, “Apie tautišką muziką" [On National Music]. Naujoji Romuva 9/371 (1938).

Vytautas Bacevičius, "Dar apie tautišką muziką" [Again About National Music]. Naujoji Romuva 15-16/377-378 (1938): 370-371.

23 That was due to several reasons, the most important of which was the fact that after World War II most of the interwar modernist compositions remained inaccessible to performers for several decades; all the avant-garde opuses of Kačinskas and some compositions by Jakubenas from the years of his studies and the war period were believed to have been lost, and the symphonic works of Bacevičius were still unpublished.

24 This article was written as a part of the project "Lithuanian History and Mythology on Opera Stage", funded by the Research Council of Lithuania. 
Osvaldas Balakauskas, "Praradimai ir atradimai" [Loss and Discovery]. Literatūra ir menas (4th February 1978).

Vladas Jakubėnas, "Moderniosios muzikos krizè" [The Crisis of Modern Music]. Vairas 2 (1933): 213-218.

Vladas Jakubėnas, "IV Filharmonijos koncertas" [The Fourth Philharmonic Concert]. Lietuvos aidas (10th January 1934): 8.

Vladas Jakubènas, "Tautinès muzikos klausimais. Atsakymas V. Bacevičiui” [On the Issues of National Music. Answer to V. Bacevičius]. Naujoji Romuva 14/376 (1938) 346-348.

Vladas Jakubėnas, "Kaip augo mūsų muzika" [How Our Music Grew]. Lietuvos aidas (15th February 1938): 5 .

Małgorzata Janicka-Słysz, Vytautas Bacevičius i jego idee muzyki kosmicznej [Vytautas Bacevičius and his Ideas of Cosmic Music]. Kraków: Akademia Muzyczna w Krakowie, 2001. Jeronimas Kačinskas, "Naujoji čekų muzika” [New Czech Music]. Muzikos barai 2 (1931). Jeronimas Kačinskas, "Tautiškos lietuvių muzikos kūrybos klausimai” [On Issues of the Lithuanian National Music]. Muzikos barai 2 (1933): 21-23.

Jeronimas Kačinskas, "Muzika Lietuvoje” [Music in Lithuania]. Naujoji Romuva 47/400 (1938). Jeronimas Kačinskas. Gyvenimas ir muzikine veikla. Straipsniai, laiškai, atsiminimai, [Jeronimas Kacinskas. Life and Musical Activities. Articles, Letters Memoirs]. Edited by Danutė Petrauskaitè. Vilnius: Baltos lankos, 1997.

Vytautas Landsbergis, "Pūtè vejas akmenį" [The Wind Blew the Stone]. Literatūra ir menas (4th February 1978).

St. Mac., "Kompozitorius Jeronimas Kačinskas apie muzikos festivali Londone" [Composer Jeronimas Kačinskas on the Music Festival in London]. Vakarai (9th July 1938).

“Naujas V. Bacevičiaus kūrinys" [V. Bacevičius's New Work]. Muzikos barai 3 (1932): 38.

Rita Nomicaitè, “Vladas Jakubėnas (1904-1976)." In Lietuvos muzikos istorija, Kn. 2: Nepriklausomybes metai, 1918-1940. Edited by Algirdas Ambrazas. Vilnius: Lietuvos muzikos ir teatro akademija, 2009: 587-599.

Rūta Stanevičiūtè, Modernumo lygtys. Tarptautinè šiuolaikinès muzikos draugija ir muzikinio modernizmo sklaida Lietuvoje [Figures of Modernity. International Society for Contemporary Music and the Modern Music Movement in Lithuania]. Vilnius: VDA, 2015. Vytautas Bacevičius in Context Edited by Rūta Stanevičiūtè, Veronika Janatjeva. Vilnius: Lithuanian Composers' Union, 2009.

Vytautas Bacevičius. II tomas. Išsakyta žodžiais [Vytautas Bacevičius. Volume 2. Put into Words]. Edited and transl. by Edmundas Gedgaudas. Vilnius: Petro Ofsetas, 2005. 
Rūta Stanevičiūtè - full-time professor at the Department of Musicology of the Lithuanian Academy of Music and Theatre. Her current fields of interest are modernism and nationalism in twentieth- and twenty-first century music, philosophical and cultural issues of contemporary music, music and politics, and studies of music reception. She has conducted research at the universities of Warsaw, Cambridge, and King's College London, the Berlin University of Arts, Paul Sacher Foundation, Darmstadt Music Institute and other institutions. She is the author of the book on the International Society for Contemporary Music and the Lithuanian musical modernism (2015) and co-author of the monographs on Cold War and internationalization of Lithuanian music (2018) and microtonal music in Central and Eastern Europe (2020). She edited and co-edited over twelve collections, including volume on music philosophy for Springer (2019). From 2005 to 2010, she was chair of the Musicological Section at the Lithuanian Composers' Union, and since 2020 she is an editor-in-chief of the journal Lithuanian Musicology. She awarded the Lithuanian National Prize for Culture and Arts in 2020.

\section{BIOG R A M}

Prof. Rūta Stanevičiūtè - jest pracownikiem Wydziału Muzykologii Litewskiej Akademii Muzyki i Teatru. Jej zainteresowania ogniskują się obecnie na zagadnieniach modernizmu i nacjonalizmu w muzyce Xx i XxI wieku, filozoficznych i kulturalnych aspektach muzyki współczesnej, związkach muzyki z polityką, a także problemach percepcji muzyki. Autorka prowadziła badania na uniwersytetach w Warszawie, Cambridge, w King's College w Londynie, berlińskim Uniwersytecie Sztuk Pięknych (Universität der Künste), Fundacji Paula Sachera, Internationales Musikinstitut Darmstadt i wielu innych instytucjach. Jest autorką książki o Międzynarodowym Towarzystwie Muzyki Współczesnej i litewskim modernizmie muzycznym (2015), współautorką monografii o zimnej wojnie i internacjonalizacji muzyki litewskiej (2018), muzyce mikrotonowej w Europie Centralnej i Wschodniej (2020), a także redaktorką lub współredaktorką kilkunastu publikacji zbiorowych, w tym zbioru o filozofii muzycznej (Springer 2019). W latach 2005-2010 była przewodniczącą Sekcji Muzykologów Związku Kompozytorów Litewskich. Od 2020 roku jest redaktorem naczelnym pisma „Lithuanian Musicology”. W tym samym roku otrzymała Litewską Nagrodę Państwową $\mathrm{w}$ dziedzinie kultury i sztuki.

\section{STRESZCZENIE}

„Stwórzmy nowoczesna Litwę!" Konfrontacja tożsamości narodowej i nowoczesności w dyskursie o modernizacji muzyki litewskiej w latach $30 . \mathrm{x}$ x wieku 
The project of modernisation, which emerged as the central idea in the course of $2 \mathrm{O}^{\text {th }}$-century Lithuanian music, predetermined many creative orientations and discoveries by Lithuanian composers of various generations, as well as critical reflection on their works. At the root of Lithuanian projections of musical modernism lies a central concern with questions of national identity, affected by crucial historical changes and political processes. In this paper, I explore issues of relationship between construction of national identity and the modernity, focusing in particular on public discussions concerning national and modern elements in music, which appeared in the musical press of the 1930 s and became emblematic of subsequent Lithuanian music history. Among the most active participants of the debates were young composers and musicians who had set up the Society of Progressive Musicians in 1932 and the ISCM Lithuanian Section in 1936: Vytautas Bacevičius, Jeronimas Kačinskas, and Vladas Jakubènas. Their opinions marked a significant turning point in the national music discourse, updating and expanding the understanding and use of the concepts of modern and national music in Lithuania. The interwar polemical observations, insights and statements were effectively elaborated in later reception and served as basis for a reinterpretation and revision of the Lithuanian music modernisation discourse.

KEY WORDS Lithuanian music modernisation, national identity, Vytautas Bacevičius, Jeronimas Kačinskas, Vladas Jakubènas
Projekt modernizacji był naczelną ideą w muzyce litewskiej Xx wieku. Idea ta zdeterminowała powstanie wielu kierunków twórczych i odkryć kompozytorów litewskich różnych pokoleń, a także krytyczną refleksję nad ich dziełami. U podstaw litewskich dążeń modernizmu muzycznego leży kwestia tożsamości narodowej, na którą wpływ miały kluczowe zmiany historyczne i procesy polityczne. W niniejszym artykule badam niektóre zagadnienia dotyczące relacji między konstrukcją tożsamości narodowej a nowoczesnością, skupiając się w szczególności na publicznych dyskusjach na temat elementów narodowych i nowoczesnych w muzyce, które pojawiły się w prasie muzycznej lat 3o. i stały się emblematyczne dla późniejszej historii muzyki litewskiej. Do najbardziej aktywnych uczestników debat należeli młodzi kompozytorzy i muzycy, którzy w 1932 roku założyli Stowarzyszenie Muzyków Postępowych, a w 1936 roku Litewską Sekcję MTMW - Witold Bacevičius, Jeronimas Kačinskas i Vladas Jakubėnas. Ich opinie stanowiły punkt zwrotny w dyskursie o muzyce narodowej, aktualizując i rozszerzając rozumienie i stosowanie pojęć muzyki nowoczesnej oraz narodowej na Litwie. Polemiczne obserwacje, spostrzeżenia i wypowiedzi z okresu międzywojennego zostały efektywnie rozwinięte w późniejszej recepcji i posłużyły jako podstawa do reinterpretacji i rewizji dyskursu o modernizacji muzyki litewskiej.

Stowa KLUczowe modernizacja muzyki litewskiej, tożsamość narodowa, Vytautas Bacevičius, Jeronimas Kačinskas, Vladas Jakubènas 